\title{
Natural Disasters and the European Printed News Network
}

\author{
Carlos H. Caracciolo*
}

\section{Introduction}

The circulation of news about natural calamities in early modern Europe can be analysed from different points of view. This text will concentrate on the development of the news network about natural disasters in the context of the history of the circulation of news, from its beginning with manuscript newssheets or avvisi through to the complex and more fully articulated network developed throughout Europe in the eighteenth century. In particular, I will focus on the news that crossed political or linguistic borders. It is no easy task to consider this subject exhaustively. One of the crucial points is the quantities to consider: the volume of sources, which is to say handwritten news, news pamphlets (relations, broadsheets) and newspapers (or gazettes) on the one hand; on the other, the number of events. For instance, the European Archive of Historical Earthquakes Data (AHEAD) counts 204 'large' and 'extra large' events in Europe and western Turkey between 1501 and $175^{0} .^{1}$ Digital humanities helps significantly in this area of research through the digitisation and the uploading of more and more documents, but the corpus is not yet large enough to cover the whole mass of news and events. The calamities selected are those caused by geophysical activity like earthquakes, volcanic eruptions, landslides, floods, and storms. Each type of event has different spatiotemporal development and this affects the ways in which they were communicated.

\section{Natural Disasters at the Beginning of the Sixteenth Century: Marino Sanudo and the information network}

Scholars agree that the origin of the regular circulation of news is found in the commercial correspondence that circulated through a variety of means

* I would like to thank Viviana Castelli and Brendan Dooley, who shared some of the sources with me, my wife, Michela Sandias, and Joad Raymond who patiently read the text.

1 See $<$ www.emidius.eu/AHEAD/main/ $>$ [2/5/15].

(C) CARLOS H. CARACCIOLO, 2016 | DOI 10.1163/9789004277199_034 
throughout Europe, as well as in the letters sent by the ambassadors of Italian courts to their princes and to the popes during the Italian Renaissance. ${ }^{2}$

Giovanni Villani reported, in his well-known Cronica, an earthquake that struck the region of the present-day border between Austria, Italy and Slovenia in 1348, some weeks before the Black Death. Villani argued that to report the event accurately and without mistakes, he preferred to copy a letter sent by "our Florentine merchants who deserve truth". Down to the present, Villani's copy of the letter has been one of the most important sources for the study of this earthquake, and can be adduced as early evidence of the presence of natural disasters in the history of information and news. ${ }^{3}$

Another important viewpoint for assessing the relationship between the circulation of news and natural disasters at the beginning of the sixteenth century is represented by Marino Sanudo's Diarii. The Venetian historian, who belonged to the political elite, kept a diary of occurrences in Venice and elsewhere, which he got to know about through the Republic's diplomatic and administrative network. When an earthquake rocked Bologna on the last day of 1504 (and the tremors continued until the 20 January 1505), Sanudo's report was based on letters: "From Bologna I saw letters of the 21st of January. [They tell] how earthquakes did tremendous damage there". ${ }^{4}$ It is not clear whether the letters referred to were avvisi-a conventional news medium, in other words-because Sanudo did not mention the author (as he usually did), but probably they were private letters. Three years later, when Crete (then a Venetian dominion) was struck by a series of strong earthquakes, Sanudo reported in his Diario, alongside a private letter from a Venetian official, an excerpt from a "very notable chronicle". It is not clear even in this case what type of text this was: it seems to have been anonymous and directed to a larger public rather than to the authorities. ${ }^{5}$

Marino Sanudo wrote many notes about another earthquake which, on 26 March 1511, struck Carniola (now Slovenia) and Friuli, in north-eastern Italy,

2 Mario Infelise, 'News Networks between Italy and Europe', in The Dissemination of News and the Emergence of Contemporaneity in Early Modern Europe, ed. Brendan Dooley (Farnham: Ashgate, 2010), p. 54; see also the references there.

3 Giovanni Villani, Cronica, 4 vols. (Florence, 1845), 4:183-5. Christa Hammerl, 'The earthquake of January 25th, 1348: discussion of sources', in Historical Investigation of European Earthquakes, ed. Paola Albini and Andrea Moroni (Milan: CNR, 1994), vol. 2, pp. 225-40.

4 Marino Sanudo, Diarii, 58 vols., ed. Federico Stefani et al. (Venice: F. Visentini, 1879-1903), 6: 130.

5 Sanudo, Diarii, 7: 570-2. Nicholas Ambraseys, Earthquakes in the Mediterranean and Middle East. A Multidisciplinary Study of Seismicity up to 1900 (Cambridge: Cambridge University Press, 2009), pp. 417-22. 
mainly on the basis of official letters and on his own experience of the earthquake, which was also felt in Venice. Sanudo mentioned only the avvisi from Milan, which reported that the earthquake had caused a little damage in Bergamo but that it had not been felt in Milan. ${ }^{6}$ This is the sole trace of news circulating about this event on the southern side of the Alps. On the other side, a verse account of the event was printed in Munich, written in the first person: About the earthquake that occurred in the eleventh year. ${ }^{7}$ The text mixed personal experience of the earthquake, spiritual or religious reflections, and factual information about the event. Perhaps this text does not belong to the genre of the typical news pamphlets of the ensuing decades. Yet it can be considered an actual report about what had happened in the lands hit by the earthquake.

In 1522, another strong earthquake struck the kingdom of Granada, Morocco and the Azores Islands. On this occasion Sanudo clearly identified his source: "Through news that Our Lord has from Spain, it is known that in Africa, on 22 September, there was such an earthquake the like of which has have never been heard of, since the world was created". ${ }^{8}$ The account is long and detailed, giving news of the consequences of the earthquake in the cities of Fez, Tlemcen and in the castle of Peñon de Velez, as well as about the impact in the environs. It continued with news about the effects of the earthquake in southern Spain, particularly Almeria.

While in Venice the news about these events came through manuscript newssheets, in northern Europe they were diffused by printed news pamphlets. In Antwerp and in Cologne a letter was published by an official of the Portuguese crown, a certain Manuel Borges, along with another letter received by Borges himself, with news about the effects of the earthquake in northern Africa and Spain. ${ }^{9}$ Seismologists say there were at least two different events. ${ }^{10}$ At all events, private letters became news when they were translated into French and German to be sold to a broader public." News about this

6 Sanudo, Diarii, 12: 109-10.

$7 \quad$ Vom Erdpidem Anno etc. im aylfften jar beschehn (München, 1511): two editions are available on <www.zvdd.de/> [2/5/15].

8 Sanudo, Diarii, 33: 578.

9 Nancy Joe Dyer, 'La relación del terremoto en el Mediterraneo, 1504-1542', in España y el mundo mediterráneo a través de las relaciones de sucesos (1500-1750), ed. Pierre Civil, Françoise Crémoux and Jacobo Sanz (Salamanca: Universidad de Salamanca, 2008), pp. 145-6.

10 Cf. José Manuel Martinez Solares, 'Catalogo Sismico', in Sismicidad histórica del Reino de Granada (1487-1531) (Madrid: Instituto Geográfico Nacional, 1995), no. 12, pp. $20-6$.

11 Dyer, 'La relación del terremoto', pp. 146-7. 
earthquake was also printed in Augsburg with a report about a strange phenomenon in Rome, which was religiously interpreted. ${ }^{12}$

Despite the newssheet's role in providing information about the earthquake in Spain and Morocco, private letters still seem to have been the main source of information for the Venetian Great Council. For example, a letter arrived in Venice from the Venetian consul in Naples, Lunardo Anselmi, about a violent storm and flood which caused extensive damage in the city and the surrounding lands in October $1523 \cdot{ }^{13}$ Instead, news about the same event (sent by a certain Jobst Ludwing) was printed and published the same year in German with other news from the Netherlands, Rome and Austria. ${ }^{14}$

In 1531, a news pamphlet printed in Valencia (Spain) reported the strong earthquake that struck Lisbon and central Portugal on 26 January that year, causing much damage and many fatalities. Another edition was published, probably in the same year, also in Spanish. We do not know if there was other printed news of the Lisbon earthquake. Yet it seems that this event was little heard of outside the Iberian Peninsula. According to Sanudo, the information reached Venice through Rome: the Venetian ambassador in Rome wrote that the pope had told him that a huge earthquake had occurred in Lisbon. ${ }^{15}$

Some months before, during the cold and rainy autumn of 1530, the Tiber River had burst its banks in Rome and the sea had flooded Flanders, both incidents causing huge calamities and many casualties. Information from Rome came to Venice through private letters. Sanudo added to his diary an anonymous letter (likely a manuscript newssheet) received by the Duke of Mantua. Yet in French as well as in German at least four relations were printed about the Tiber floods to inform a large public about what had happened in the papal city. The flood in the Low Countries was reported in at least one news pamphlet printed in French and another in German. ${ }^{16}$ Meanwhile in Venice, Marino Sanudo reported news that Pandolfo Cenami had received from Antwerp. Cenami was probably the most important Venetian banker at that time. He received a continuing flow of news from Antwerp, as well as from Lucca, Lyon

12 Von der Finsternus die zü Rom geschehen ist ... auch in andernkünigreichen / etlich stet durch Erdbidem undergangen / uñ nydgefallen seinnd (Augsburg, 1522), USTC 703465. Edition available at $<$ www.zvdd.de/ $>$ [2/5/15].

13 Sanudo, Diarii, 35: 135 .

14 Newe Zeitung aus dem Niderlandt auss Rom auss Neapolis (n.p., 1523), ustc 677736. See Emil Weller, Die ersten Deutschen Zeitungen (Tübingen: H. Laupp, 1872), p. 91, no. 16. Available at $<$ www.archive.org $>[2 / 5 / 15]$.

15 Sanudo, Diarii, 54: 308-9. See also Dyer, 'La relación del terremoto', pp. 147-8.

16 Weller, Die ersten, p. 103, nos. 53-4. 
and Paris. ${ }^{17}$ It is worth noting also that the sources of the news pamphlets printed in Lyon about the inundation of Rome were letters sent to bankers established in Paris and Lyon. ${ }^{18}$

Sanudo's Diaries end in September 1533. By that time news pamphlets about political events had circulated in Italy for some years already. However, it seems that printed news about natural disasters circulated mostly in northern Europe, while in Venice (and probably also in Rome) this type of news circulated through avvisi, and that they reached a smaller audience than the northern European prints.

\section{Natural Disasters and News Networks in the Sixteenth Century}

In March 1536, a few years after the Portugal earthquake, Mount Etna erupted in Sicily. The eruption was accompanied by several strong earthquakes. The Benedictine monastery of San Leone was first destroyed by the quakes and then buried by lava, which also threatened Catania. On this occasion a news pamphlet was published in Italian. ${ }^{19}$ This may be the first printed news about a natural phenomenon to have been published in Italy. In German a news pamphlet about the eruption was issued by an unknown printer. Probably it circulated reasonably widely, since Emil Weller has found copies of it in five libraries. ${ }^{20}$ Two years later, in September 1538 , there was an exceptional volcanic eruption in the Phlegraean Fields, near Naples, which destroyed the town Tripergole, seriously damaged Pozzuoli and formed a new peak (Monte Nuovo). Information about the extraordinary phenomenon was disseminated in German by at least two news pamphlets, one of them issued in Augsburg. A French-language print was issued in Lyon. ${ }^{21}$

17 Jean-Pierre Seguin, L' information en France avant le périodique (Paris: Presses Universitaires de France, 1964), pp. 84-5. About the banker, see: Maria Rosa Pardi Malanima, 'Pandolfo Cenami', in Dizionario Biografico degli Italiani, <www.treccani.it/ enciclopedia/pandolfo-cenami_\%28Dizionario-Biografico\%29/> [25/10/13].

18 Seguin, L'information, p. 84, nos. 123-7.

19 Li horrendi, \& spaventosi prodigij, \& fuochi aparsi in Sicilia nel Monte de ethna overo Mongibello. See Tullio Bulgarelli, Gli avvisi a stampa a Roma nel Cinquecento (Rome: Istituto di studi romani, 1967), p. 48, no. 34.

20 Erschrökliche warhafftige newe Zeittung, die sich mit grausamen erdbidem un feur in Sicilia. See Weller, Die ersten, p. 117, no. 103. Copy on <www.zvdd.de> [2/5/15].

21 Copie dune Lettre venue de Naples contenant les terribles et merveilleux Signes et prodiges advenuz au lieu et Ville de Pozzol (Lyon, 1538), ustC 73644. See Seguin, L'information, p. 91, no. 188 . 
In 1542, the earthquake of the Mugello Valley (Tuscany) reached an even wider European public. There were two or three letters written and printed in Florence giving news of the event. These documents were the sources of different European editions, with translations following in French, English, German and Dutch. ${ }^{22}$ In one Italian edition, the author finished with a note about another phenomenon and an interesting comment: "About what has been seen in the city of Sebenico, in the Levant, in a Jews' place and in other parts of the Turk Lord, I think that His Grace was well informed, better than me, considering you are in Rome [...] where all things come soon". ${ }^{23}$ We do not know the subject of this comment. However, in the abovementioned editions published in German and French included news of another catastrophic event in the Turkish lands: "Also news about what happened in Turkey, where a city sank into the earth, so that nobody survived". In another news pamphlet printed in German in two editions, the order of the news is inverted: the text begins with the news about some miraculous signs that had been seen in Stabonicchio, Judea. It continues with the news about a monstrous child that was born in Maremma, in southern Tuscany, and then with the Mugello earthquake. ${ }^{24}$ In Strasbourg a news pamphlet was printed which reported only on the event in the Levant. In the titles of the editions printed in London and Antwerp the event is referred to only in the following terms: "Also how that a cytie in Turky sank". It is not known precisely what that Ottoman event was, nor where it happened: only that it occurred a short time before the Tuscan earthquake. In 1691, Marcello Bonito mentioned an earthquake in Palestine that had occurred in around $1541 .{ }^{25}$ So far, seismological historiography has not identified this event, pointing only to a wellknown earthquake that rocked Palestine in $1546 .{ }^{26}$ Here the interesting point is that both news events somehow shared the same network over a large part of Western Europe. This is conspicuously not true of another event, news of which apparently circulated only within Spanish-speaking regions. The year of the Mugello earthquake an excerpt of a letter was printed in Seville which reported the flood and landslide that had destroyed

22 Seguin, L'information, p. 91, no. 189. Weller, Die ersten, p. 117, no. 103.

23 Fillipo Bellandi and Dennis E. Rhodes, eds., Il terremoto del Mugello del 1542 in un raro opuscolo dell'epoca (Florence: Comunità Montana zona E, 1987).

24 See Weller, Die ersten, p. 133, no. 148.

25 Marcello Bonito, Terra tremante o vero continuatione de' terremoti dalla creatione del mondo fino al tempo presente (Naples, 1691), p. 684.

26 See Ambraseys, Earthquakes in the Mediterranean, p. 440, in which is reproduced the first page of the news pamphlet printed in Strasbourg. 
the town of Guatemala the year before. ${ }^{27}$ The letter had been printed the same year of the event in Mexico: Relation about the fearful earthquake that recently happened in the West Indies, in a city named Guatimala. ${ }^{28}$ Current scholarship suggests that this is the first news pamphlet published in the Americas. ${ }^{29}$ Yet the main point is that this news seems to have been diffused only in Spain or in the Spanish-speaking territories, without crossing the Pyrenees.

On the other side of the Mediterranean basin, beside the Venetian dominions, there was the vast territory conquered by the Ottoman Empire, which was frequently hit by natural disasters. News of some of these phenomena reached European readers. In 1545 a news pamphlet printed in German but of uncertain typographic origin reported an earthquake that same year on 24 March, in central Greece. According to the title, the content was a translation of a news pamphlet printed in Verona, based on letters that had come to Venice from Corfu. Since the Italian print is not extant, the German rendering of it is one of the few detailed descriptions of this event. ${ }^{30}$ The next year, another letter reached a nobleman in Venice, probably from the coast of Palestine. This became the source of a news pamphlet published in Wittenberg in German and in Antwerp in French, which described two events: the first, a strong earthquake that hit Palestine in January, and the second, an "unusual" or "horrible" event that caused considerable damage in Famagusta, on the east coast of Cyprus. ${ }^{31}$ Again, the news pamphlet represents an important

27 Relacion cierta y verdadera sacada y trasladada de una carta que a esta cibdad de sevilla fue enbiada sobre la terrible y tempesutosa tempesta que sucedio en la cibdad de Guatimala. Catalogued by M. Agullo y Cobo and quoted by Carmen Espejo y Cala, 'El orígen epistolar de las relaciones de sucesos de la edad moderna', in La correspondencia en la historia, ed. Carlos Sáez and Antonio Castillo Gómez (Madrid: Calambur, 2002), p. 160.

28 Relacion del espantable terremoto que agora nuevamente ha acontecido en las yndias en una ciudad llamada Guatimala (Mexico, 1541), UsTC 344171. Quoted by Dyer, 'La relación del terremoto', p. 149 .

29 See Leonardo Ferreira, Centuries of Silence: The Story of Latin American Journalism (Westport, cT: Praeger, 2006), p. 56.

$30 \quad$ Weller, Die ersten, p. 137, no. 159. Ambraseys, Earthquakes in the Mediterranean, pp. 441-4.

31 Zeittung von einem grossen und erschrecklichen Erdbidem ... dadurch zu Jerusalem un inn vielen umbligenden Stedten, mercklicher schade geschehen (Wittenberg, 1546), USTC 707638. Ung merveilleusement grandt mouvement de terre, et merveilleux signes et dommages, maintenant de brief advenus en la ville et toute la province de Jherusalem ... Encoire aussi ineffables et horribles ventz, en lisle de Cypre en la ville appellee Famagosta (Antwerp, 1546), UstC 38188. See Ambraseys, Earthquakes in the Mediterranean, p. 444. 
source for the study of the event. ${ }^{32}$ In any case, the salient point is the route taken by the news: the narratives of both of the later news pamphlets were written to some noblemen in Venice, and then translated and printed. In the last case there is no mention of any print in Italian. A news pamphlet printed in two editions in Nuremberg reported two pieces of news: one is the narrative of another Middle Eastern earthquake that had struck the region of the Sea of Marmara. ${ }^{33}$ Probably the text of this pamphlet was used also in an illustrated broadsheet with an imaginary Istanbul damaged by the quakes. ${ }^{34}$ More attention was paid to the earthquake that struck Kotor in 1564, about which a news pamphlet was printed at least in three editions: in Augsburg, Nuremberg, and in another edition of uncertain origin. ${ }^{35}$ The source of the news was a report written by a Venetian high official to some noblemen in Venice. This letter was similar to those mentioned earlier, and to those copied by Marino Sanudo some decades before, but they became news when they were printed and sold.

Most of the news about Middle Eastern events was printed in German. In contrast, most of the news about the floods in Rome were printed in French. There exists a German news pamphlet, of unknown origin, about the Tiber floods of 1557 (according to a copy printed in Rome). ${ }^{36}$ Probably it was that printed by Antonio Blado, which also reported the peace between the Pope, Paul IV and King Philip. Meanwhile, two news pamphlets about the Roman flood were printed in Paris and in Rouen. ${ }^{37}$ The French news pamphlets also reported a simultaneous flood in Florence.

Though not as severe as its Middle Eastern counterparts, the case of the earthquake that rocked the Maritime Alps on 20 July 1564 is worth remarking. Although there is no news pamphlet about it published in French or Italian, Emil Weller collected two very different news pamphlets printed in German. One of them, once again of unknown origin, reports the earthquake that struck the Duchy of Savoy, not far away from Nice. The second was published in Nuremberg and tells of seven cities destroyed "by God" by means of the

32 Yet, the interpretations are differents: see Mohammed Reda Sbeinati, Ryad Darawcheh and Mikhail Mouty, 'The historical earthquakes of Syria: an analysis of large and moderate earthquakes from 1365 B.C. to 1900 A.D.' Annals of Geophysics, 48.3 (2005), pp. 347-435, and Ambraseys, Earthquakes in the Mediterranean, pp. 444-51.

33 Weller, Die ersten, p. 154, no. 206.

34 See Ambraseys, Earthquakes in the Mediterranean, p. 455, fig. 3.25.

35 Weller, Die ersten, pp. 178-9, no. 271.

36 Weller, Die ersten, p. 156, no. 210.

37 Seguin, L'information, p. 85, nos. 130-1. 
earthquake. ${ }^{38}$ The phenomenon was one of the most important of that region. It destroyed at least the towns of La Bollène, Belvedere and Roquebillier, with significant damage recorded in four other towns. ${ }^{39}$

During the ensuing years the European peoples suffered other natural calamities, as for instance the large floods, according to the news, during the autumn of 1567 along the course of the Adige river, across Trent, Verona, Padua and Vicenza in northern Italy. The narrative also mentions small towns such as Legnano and recalls the flood in the same region in $1512 .{ }^{40}$ During the following year, this news was also printed in two editions in Augsburg, Nuremberg and Berger in Strasbourg. In spite of the interest that this event generated in Germany, there are no news pamphlets about it in any other languages, not even in Italian.

Three years later, in the autumn of 1570, other calamities hit at least three European lands: floods in the Low Countries as well as France, and an earthquake in Ferrara, in northern Italy. Ferrara was struck by the earthquake when the city was enjoying the high cultural prestige given by the House of Este. The quake struck the night of $16 / 17$ November, the first of a swarm that lasted until 1574. The death toll was between 30 and 40 people, yet the damage to buildings and the continuous quakes led to the migration of a significant proportion of the inhabitants, with Duke Alfonso II forced to abandon his castle. Many people and foreign diplomats interpreted the whole situation as a sign of the decadence of the House of Este. ${ }^{41}$ The Fugger network of newsletters received information a few days after the main event and went on reporting the succession of quakes over the next few months. ${ }^{42}$ Five news pamphlets were printed in German (in Zurich, Augsburg, Cologne, Erfurt, beside others without typographic indications), four in French (in Lyon and reprinted in Paris, by at least two printers, and in Rouen), one in English (in London), and a verse account was published in Spain. ${ }^{43}$ No evidence exists of any news pamphlet printed in Italian. Instead, there was an Italian printed

38 Weller, Die ersten, p. 181 , nos. $275^{-6 .}$

39 See $<$ www.sisfrance.net/documents.asp $>$ [4/5/15].

$40 \quad$ Weller, Die ersten, pp. 199-200, no. 331.

41 Cf. E. Guidoboni, G. Ferrari, D. Mariotti, Catalogo dei forti terremoti in Italia: <storing.ingv. it/cfti4med/\#> [4/5/15].

42 See for instance the correspondence from Ferrara of 21 and 25 November and 5 and 12 December 1570, available at <anno.onb.ac.at/cgi-content/anno?aid=fug $>$ [4/5/15].

43 Weller, Die ersten, pp. 211-13, nos. 364-7; Seguin, Linformation, pp. 91-2, nos. 193-7; A Coppie of the letter sent from Ferrara the xxij of Nouember, 1570 (London, 1571?), USTC 507238; B. de Flores, Relacion del espantable temblor y tempestad de rayos, que ahora ha sucedido en el mes de enero proximo passado deste año de setenta y uno, en la ciudad de 
news pamphlet about the "extensive ruins and damage to goods and other things made by the sea and rivers and large storms, that have occurred in Lyon of France, in Antwerp and in Flanders". ${ }^{44}$ News about the earthquake in Ferrara earthquake was associated in the same booklet with the news about the floods in the Low Countries. Eight different news pamphlets were printed in German: in Strasbourg, Cologne, Nuremberg, Erfurt, Augsburg and Zurich, and two more of unidentified origin. ${ }^{45}$ The Low Countries experienced another disastrous sea flood in 1582, when many hundreds of people drowned, according to a German news pamphlet. ${ }^{46}$

News about natural catastrophes was frequently published in the same prints as reports of other events: prophecies, battles, journeys of kings or queens, and so on. The war against the Ottoman Empire, the uprising of the protestant provinces of the Low Countries against the Hapsburg sovereignty, the Anglo-Spanish war, all these were all among the most important news topics during the last decades of the century. For example, in a German news pamphlet two items were reported: the first about a flood in the Parisian neighbourhood of Saint Marcel, the second, reported from Utrecht not long after the Treaty that established the Union of Utrecht, about the events related to a battle against the Spanish army. ${ }^{47}$ The bursting of the Bièvre river in Paris left 25 dead and 40 injured, and led to the loss of livestock, trees, houses and mills. The news pamphlet presented itself as the authorised translation of that printed in Paris. In fact, there were at least two news pamphlets published in Paris about this event: one of them reprinted in Orléans and in Lyon, while another pamphlet was printed in Poitiers. ${ }^{48}$

Ten years after the Ferrara earthquake, another, smaller, quake hit both sides of the English Channel. News about this was printed in two editions in Paris and Lyon. ${ }^{49}$ Nevertheless, these news pamphlets gave information only about the impact in France. Meanwhile, many news pamphlets were issued about the event on the English side of the Channel. However, it is difficult to assess

Ferrara e iuntamente como en Flandes se annegaron de una creciente cient villas y lugares (n.p., 1571), USTC 336283 See: <www.bidiso.es/RelacionesSucesosBusqueda/> [4/5/2015]. Avisi venuti nuovamente da diversi paesi della gran rovine \& danni de mercantie ... che a fatto il mare; see Tullio Bulgarelli and Sandro Bulgarelli, Il giornalismo a Roma nel Seicento (Rome: Bulzoni, 1988), p. 68, no. 107.

45 See above, note 43.

46 Weller, Die ersten, p. 277, no. 564.

47 Weller, Die ersten, p. 256, no. 502. Available at <www.digitale-sammlungen.de $>$ [4/5/15].

48 Seguin, L'information, pp. $85^{-6}$, nos. $138-42$.

49 Seguin, Linformation, p. 92, nos. 202-4. 
the 'journalistic' character of those texts; they seem rather to be religious reflections about the phenomenon. ${ }^{50}$

In March 1584 another earthquake struck a linguistic boundary region. On one side, a news pamphlet published in Strasbourg reported the earthquake that hit 'in Switzerland in Bern's territory'. On the other side, a French news pamphlet published in Troyes underlined information about French-speaking places among those that the earthquake hit hardest, which since 1536 had been subject to the Bern authorities. ${ }^{51}$ Though the earthquake that struck Austria in 1590 was stronger than those in the English Channel, Maritime Alps and Ferrara, the only news to be published about it was in German: in Nuremberg and in Cologne, as well as other unspecified locations. ${ }^{52}$ The last earthquake of the century to be reported in print occurred at the end of March 1598, in the remote province of Amasia, in north-eastern Turkey, where six towns and 60,00o people remained buried, as reported in a news pamphlet published in Augsburg. ${ }^{53}$

Rome suffered three major floods during the sixteenth century, and all of them were reported by printed news in France: beside the aforementioned events of 1530 and 1557 , they also reported an earthquake of $1598 .{ }^{54}$ Nevertheless the case of Rome does not represent the functioning of the entire news network. To evaluate the importance of natural disasters in the news network, it might be useful to compare news and events. For instance, comparison between newsprint reporting the earthquakes of the sixteenth century and the earthquakes catalogued for the same period shows that there is no direct relationship between the severity of a seismic event or other natural catastrophe (whether measured by intensity, magnitude, material and human losses), and their coverage in the press. Many major events were neglected because they happened far from the information network. By contrast, relatively mild earthquakes were reported (such as those in Ferrara or the Dover strait) compared to others that had been stronger but were less interesting, for instance those happened in southern Italy or within the Ottoman borders. ${ }^{55}$ Comparatively few seismic events crossed linguistic borders in their reporting.

5o For instance, Arthur Golding A discourse upon the earthquake that happned throughe this realme (London, 1580); see also 'Arthur Golding', in ODNB.

$5^{1} \quad$ Weller, Die ersten, p. 286, no. 598; Seguin, L'information, p. 93, no. 206.

$5^{2}$ Weller, Die ersten, p. 326, nos. 726-8.

53 Weller, Die ersten, p. 457 , no. 854 .

54 See Seguin, L'information, p. 86, no. 145.

55 The above-mentioned AHEAD counts 303 earthquakes between 1501 and 160o; among them only 46 are catalogued as 'large' or 'extra large', and 79 as 'medium' events. News pamphlets gave information about approximately twenty of them. 
As with earthquakes, most of the floods reported by the news involved the same linguistic region the printers. For instance, there was no news printed in the western regions about the Vistula floods at the end of the sixteenth century, when the river actually changed its course. ${ }^{56}$

\section{Natural Disasters between News Pamphlets and Newspapers: The Seventeenth Century}

Beside manuscript news and news pamphlets, during the seventeenth century, a third way to disseminate news spread across Europe. First in some German cities, later in the Low Countries and eventually in the rest of Western Europe, by the end of the century at least one newspaper had appeared in each of the most important languages of the continent. The large demand for news was the essential condition for the emergence of periodical printed news. Newspapers' manner of delivering information had more in common with manuscript newssheets than with news pamphlets or broadsheets. Usually the modern gazettes consisted of news from a series of recurring datelines, but were flexible enough to include correspondences from other cities or places, such as the scene of a battle or a disaster zone. The long, detailed and even contextualised accounts of events that characterised the news pamphlets was replaced by shorter, concise news. ${ }^{57}$ The loss of detail was compensated with the amount of news, potentially from the full extent the Christian world. As the title of the oldest European newspapers made plain, the modern newspaper featured news from Germany, Italy, Spain, Netherlands, England, France, Hungary, Austria, Sweden, Poland, Transylvania, Turkey and the East and West Indies. ${ }^{58}$ Nevertheless other forms of news communication, including manuscript avvisi and news pamphlets, continued and new connections were

$5^{6} \quad$ H. Maruszczak, 'Changes of the Vistula River course and development of the flood plain in the border zone of the South-Polish uplands and middle-Polish lowlands in historical times', Landform analysis, 1 (1997), pp. 33-9; Jerzy Cyberski, Marek Grześ, Malgorzata GutryKorycka, Elżbieta Nachlik, Zbigniew W. Kundzewicz, 'History of floods on the River Vistula', Hydrological Sciences - Journal des Sciences Hydrologiques, 51.5 (2006), pp. 799-817.

57 Nevertheless, it was not rare the case of news pamphlet with more rhetoric than substantial information about the event. For instance, see: Recit veritable et espouventable du tremblement de terre arrivé à la Pouille ... le zo juillet de la presente année 1627, C. Armand (Lyon, 1627). Available at <www.europeana.eu $>$ [4/5/15].

$5^{8}$ See Relation: aller Fürnemmen und Gedenckwürdigen Historien (Strasbourg), available at <digi.ub.uni-heidelberg.de/diglit/relation> [4/5/15]; and Aviso Relation oder Zeitung (Wolfenbüttel): available at < digitale-sammlungen.gwlb.de/index.php $>$ [4/5/15]. 
established between them and the new gazettes, creating a further layer in the already extended news network. Meanwhile, the natural course of the earth's life continued, including the cycle of catastrophic events, and the new mode of printed news was used to report on them from the very beginning of the newspaper era. At the same time, over the course of seventeenth century news pamphlets about natural disasters became more popular in certain countries, appearing more frequently than in the sixteenth century. ${ }^{59}$

Amongst the natural calamities to strike Europe during the seventeenth century, some resonated beyond the linguistic or national borders within which they occurred. During the first decade, two events in particular drew the attention of news readers: news pamphlets were published about the flooding of the Tiber in Rome (1606), and in the Bristol Channel (1607). Both were reported by French news pamphlets published in Paris. ${ }^{60}$ In the latter event, the sea flooded violently into the coast with a toll of 2,00o dead and huge damage to man-made structures, mainly in Wales and Somerset. The event is remembered as the worst natural disaster in Britain, though its cause remains unknown. ${ }^{61}$

The heavy rain and flooding that caused severe damages and many deaths in Barcelona and its surroundings in November 1617 occasioned at least one news pamphlet published in Spanish in Valencia, ${ }^{62}$ then in Italian in Milan (at that time under Spanish domination), and two French editions in Lyon and Paris. ${ }^{63}$ Nevertheless one of the natural disasters that generated most public interest during this period was an event in Grisons, on the border with Lombardy: on the night of 3 September 1618 a huge landslide buried the town of Piuro and wiped out more than a thousand people. Two Italian news pamphlets were published: in Milan (reprinted in Macerata) and in Viterbo.

59 At least, considering both mentioned Bulgarelli's catalogues, news about natural calamities in the seventeenth century were the $7.9 \%$ of all news pamphlets, while for the sixteenth century they represented the $2.27 \%$.

6o Seguin, L'information, p. 86, nos. 147-8. At least two news pamphlet were printed in Britain. See British Library Main Catalogue: Lamentable newes out of Monmouthshire in Wales. Contayning, the wonderfull and most fearefull accidents of the great overflowing of waters in the saide countye (London, 1607), and A true report of certaine wonderfull overflowings of waters, now lately in Summerset-shire, Norfolke, and other places of England (London, 1607).

61 See also the ввс service about this event: $<$ news.bbc.co.uk/2/hi/uk_news/england/6311527. stm> $[9 / 11 / 13]$.

62 Daños causados por las crecientes de los rios Ebro, Lobregat, Cinca, y Segre: con la grande tempestad que huvo a tres de Noviembre deste presente Año de 1617 (Valencia, 1617).

63 Bulgarelli and Bulgarelli, Il giornalismo, p. 25, no. 9o. Seguin, L'information, p. 87, n.154. 
There were also German-language accounts printed in Prague, Lindau, Konstanz and Strasbourg; and Seguin counted four French news pamphlets published in seven editions. ${ }^{64}$ An edition in English was published in London and Edinburgh. ${ }^{65}$

Other events which made a larger impact in the news network were the Apulia earthquake (1627) and the eruptions of Vesuvius (1631) and Etna (1669). The Apulia earthquake killed at least four thousand inhabitants, though some sources put the figure as high as thirty thousand. The town of Apricena lost $45 \%$ of its population and Serracapriola and San Paolo di Civitate approximately $35 \%{ }^{66}$ At least two news pamphlets about this event were printed in Naples. The pamphlet printed in Rome and written by Giovanni de Poardi was reprinted in Genoa, and in Augsburg, where it was printed in two German editions. ${ }^{67}$ In France, three different news pamphlets were published: in Paris, Lyon (reprinted in Paris) and in Grenoble. ${ }^{68}$

With regard to the eruption of Mount Etna in 1669, a recent study has identified ten 'families' of news pamphlets written in different times and places during its four months' duration. ${ }^{69}$ Some of them reached an international public: two in France through the news pamphlet edited by the Bureau d'Adresse, as a Gazette supplement, and one printed a week earlier in London. This English account was the first of three news pamphlets published by T. Newcomb, the printer of The London Gazette. The first two news pamphlets were published as a "particular narrative as it [was] collected out of several relations sent from Catania" by Heneage Finch, third Earl of Winchilsea. He

64 Erschrockenliche Zeitung wie der schöne Hauptflecken Plurs ... untergangen seye (Lindaw, 1618); Warhafftige erschrecklicheNeweZeitung vondemplötzlichen Untergang derStadtPlurs (Prague,1618): both availableat <www.zvdd.de> [4/5/15].Seealso Vondemerschröcklichen.... Untergang dess weitberühmbten Flecken Pluers (Strasbourg, 1618) and Warhafftige Erbarmliche und zuvor unerhörte newe Zeitung ... wie Gott der Herr durch ein Sturmwind ein grossen Berg eingesturtzt (Costantz, 1618); Seguin, L'information, p. 93, nos. 209-14.

65 See BL Main Catalogue <www.bl.uk/> [4/5/15]: Newes from Italy. Or, a prodigious and most lamentable accident lately befallen: Concerning the swallowing vp of the whole Citty of Pleurs (London, 1618), reprinted by Andro Hart (Edinburgh, 1619).

66 E. Guidoboni, G. Ferrari, D. Mariotti, Catalogue of strong earthquakes in Italy 4 61 B.c. -1997: $<$ storing.ingv.it/cfti4med/> [9/11/13].

67 One of them as broadside. See the British Museum's copy at <www.britishmuseum.org/ research/collection_online/collection_object_details.aspx?assetId=247406001\&objectId $=1449976 \&$ partId $=1>$ [4/5/15].

68 Seguin, L'information, p. 94, nos. 216-19.

69 Raffaele Azzaro and Viviani Castelli, L'eruzione etnea del 1669 nelle relazioni giornalistiche contemporanee (Catania: INGV - Le Nuove Muse Editrice, 2013). 
was in Catania and Naples in April 1669, on his return journey to London from Istanbul, where he had been England's ambassador. The last is Finch's letter from Naples to the King, and was advertised in The London Gazette as a supplementary issue. Its reach was larger than that of the others: through a series of reprintings, it reached Dublin, Edinburgh and even Cambridge, Massachusetts. Another 'family' of news pamphlets was translated and reprinted in Lisbon by Antonio Craesbeek de Mello, the printer of Mercurio Portugues. It is worth underlining that these French, English and Portuguese news pamphlets were published by the printers of the respective official newspapers. This seems to indicate that the birth of 'privileged' or official government news periodicals also conditioned the market for news pamphlets. ${ }^{70}$

\section{Natural Catastrophes and the New Style of Information}

Despite their wide diffusion, news pamphlets were gradually losing ground. This is particularly noticeable during the eighteenth century. The reason for this decline cannot only be explained by reference to the development of journalism and the growth of periodical newspapers. Probably, the decreasing diffusion of news pamphlets was brought about by the commercial conditions of the Ancien Régime, a time when privileges and monopolies were the norm. In any case, the diffusion of newspapers established a different way to be informed about natural events. The main difference is represented by the quantity of information. News pamphlets usually gave detailed information about a single event; by contrast, newspapers usually gave a few lines of information about several. Moreover, if on the one hand the content of a news pamphlet had to be an important event that deserved a title and an issue of its own (or, at least, shared the space with at most one other relevant piece of news), news in newspapers could consist of an account in a few words of one event, which would not necessarily have to be dramatic but would necessarily be significant. For instance, in the pages of both the oldest newspapers we find information of an earthquake felt in Lombardy on 9 July 1609 , which cause-according to the

70 On news pamphlets and newspapers, see Carmen Espejo Cala, 'Gacetas y relaciones de sucesos en la segunda mitad del XVII: una comparativa europea', in Géneros editoriales y relaciones de sucesos en la Edad Moderna, ed. Pedro M. Cátedra and Maria Eugenia Díaz Tena (Salamanca: SEMYR, 2013), pp. 71-88. 
news - considerable fright but relatively little damage. ${ }^{71}$ Similarly, a few weeks later, the report of a strong earthquake that caused extensive damage in Calabria occupied a few lines in these newspapers. ${ }^{72}$ More information about the earthquake was published in the following issue, but still with a far less detail than a typical pamphlet. Despite this apparent limitation, the advantage of newspapers is clear: no news pamphlets are known that report this earthquake, let alone the one felt in Lombardy.

Grégory Quenet has underlined some of the limitations of the newspaper established by Théophraste Renaudot in Paris in 1631. According to Quenet, natural catastrophes were not among Renaudot's priorities, and he did not give them much space in the Gazette's pages. Although news about natural catastrophes was "rare and uneven", the Gazette tended to carry more information about foreign events than about domestic ones. ${ }^{73}$ Since French readers were better informed about events that happened in foreign lands, even those a long way off, it is useful to take an overview of how the Gazette, as well as news pamphlets, disseminated the news of a striking event, such as the eruption of Vesuvius.

After a period of about five centuries of quiescence, Mount Vesuvius started erupting on 16 December 1631 . The eruption destroyed many villages and lands around the volcano, and the crater itself collapsed. The death toll was between 6,000 and 10,000 people. ${ }^{74}$ In Italy many news pamphlets were published about it: at least three in Naples and two in Rome, with reprints in Bologna, Florence and Venice. ${ }^{75}$ Abroad, a Neapolitan edition, written by Father Giacomo Milesio, was translated and printed in Munich and Cologne (as a broadside). The report written by Antonio Gerardi, author of other news pamphlets, was first printed in Rome and Bologna, and then in two German editions published in Augsburg,

71 "From Rome, 18 July. In the whole Lombardy it was felt on the 9th of mentioned [July] a rather big earthquake, which caused no little fright amongst the inhabitants": Aviso, Relation oder zeitung, no. 29 (2 August 16o9); and Fürnemmen und gedenckwürdigen Historien, no. 31, dateline "Auss Rome, vom 18 Julii", with a little longer correspondence. Both are available at $<$ goo.gl/dgRyxR $>$ and $<$ digi.ub.uniheidelberg.de/diglit/relation $>$ [4/5/15]. See also Johannes Weber, 'The earlier German Newspaper: A Medium of Contemporaneity' in The Dissemination of News, ed. Dooley, pp. 69-79.

72 "From Rome, 8 August ... In the Kingdom of Naples, in the city of Piastro had happened a big earthquake, which destroyed many houses, and the people had fled to the open air". Aviso Relation oder zeitung, no. 32 (23 August 1609). and Fürnemmen und gedenckwürdigen Historien, no. 35, dateline: 'Auss Rome, vom 15 August'. See note 75 .

75 Bulgarelli and Bulgarelli, Il Giornalismo, pp. 59-65. 
one of them as a broadside. ${ }^{76}$ In France, Milesio's text was printed in Lyon. ${ }^{77}$ Strikingly, the printing of Renaudot's Gazette had started just a few months before. The first news about the eruption was published a month and a half after it began, through the correspondence from Venice, dated 7 January 1632: "In the mount Somma, in front of Naples, a breach two leagues long opened up, from which there issued a huge quantity of fire and smoke, so that all dwellers nearby escaped" ${ }^{78} \mathrm{~A}$ few days later further news arrived, without a clear dateline but with more details of the event:

From Italy ... The fire of mount Somma, that is Vesuvius, three leagues from Naples, has been burning since 15 December, and it has already caused damages of two million in gold of damages, and the panic it has caused is like the image of the Last Judgement. ${ }^{79}$

On 6 February 1632 the Gazette mentioned the eruption in three correspondences: one in the first part of the issue, with news from Rome, dated 12 January, in which the writer hinted at the eruption in relation to a possible flood in the city. In the second part of the same issue, two other letters were published, from Rome and Venice, also dated 12 January. In the letter from Rome there is a thirteen-line text with details of the situation, describing the effects of the quakes produced by the volcano. Meanwhile the Venetian letter had more of a moral character: according to the correspondent, the penitence of the people of Naples had contributed to the diminution of the damage, citing as proof twenty-five promiscuous girls who had changed their ways. ${ }^{80}$ After two weeks further information arrived from Rome, dated 26 January, with three items of news: the destruction of two towns (probably by

${ }_{7} 6$ Warhaffte Relation dess erbärmlichen und erschrecklichen Zustands, so sich in der Seyten dess weitberümbten Bergs Vesuvii (Cologne, 1632). Antonio Gerardi, Warhaffte Relation, Von dem erschröcklichen Erdbidem vnd Fewrsgwalt, so auß dem Berg zu Somma (Augsburg, 1632?). Available at: <daten.digitalesammlungen.de/bsboooo1437/image_6> [5/5/15]; Eygentlicher Abriß und Beschreibung Deß grossen Erdbebens, und erschröcklichen brennenden Bergs im Königreich Neapolis <www.britishmuseum.org/research/collection_online/ collection_object_details.aspx?objectId=142516o\&partId=1\&searchText=vesuvius $+1631 \&$ page $=1>[4 / 5 / 15]$.

77 Jacques Milesius, Récit véritable du misérable et mémorable accident arrivé en la descente de la très renommée montagne de Somma, autrement le Vésuve (Lyon, 1632).

78 Gazette (30 January 1632), 34. The Gazette is available at <gallica.bnf.fr/ark:/12148/ cb32780022t/date> [4/5/15].

79 Gazette (4 February 1632), 46.

8o Gazette (6 February 1632), 56. 
the pyroclastic flows), the bankruptcy of the prince of Ottaiano (whose fief was located right at the foot of the volcano), and the changes in the features of the crater. ${ }^{81}$ In the next issue of the Gazette, the news was no longer from Rome or Venice but from Naples itself. A long letter from Naples dated 4 February 1632 marks the activation of another segment of the news network. From that issue onwards, the reader of the Gazette had direct news about the progress of the event and about the social reaction to the disaster. News of the eruption came from Naples almost weekly for two months, at which point the volcano's activity apparently ceased, as well as the news datelined from Naples, which became rare. ${ }^{82}$

\section{Natural Catastrophes and the Functioning of News Networks}

Newspapers incorporated the news pamphlet into their own system and increased the level of sensitivity to natural phenomena. In addition, the European news network operated better where there was an efficient circulation of news at local or national level. Even in the case of a very politically and militarily oriented newspaper, like the Torinese Successi del Mondo, when a heavy earthquake rocked Gargano in 1646, the network was able to provide news for a public which was sensitive to this type of information, even if the news item itself was relatively brief. ${ }^{83}$ In particular, the editor of the Successi, Pietro Antonio Socini, was so concerned with supporting the French interest in Piedmont, particularly at that moment, when naval battles were taking place between the French and Spanish navies near the Tuscan coast, that he neglected to write from where the news about the earthquake came and when it had happened. Probably Socini had received the same news the French Gazette had issued with the dateline of "Ancona, 13th of June 1646", but before publishing he had cut and synthesised it. This explains why the Parisian newspaper gave considerably more information. ${ }^{84}$ Later, while the French newspaper published a second piece of news received from Naples about the

$81 \quad$ Gazette (20 February 1632), 71.

82 In October a letter from Rome (dated 11 September 1632) was published which commented on the reaction of the Neapolitan people in front of new signs of activity of the volcano: "The fire of Mount Vesuvius restarted, but the custom, as usually happens, reduces the surprise" Gazette (8 October 1632), p. 401.

83 See Successi del mondo (Torino, 19 June 1646). I thank Brendan Dooley, for having kindly shared with me the copies of this newspaper.

84 See Gazette (14 July 1646), 562. 
earthquake, Successi del Mondo had no correspondent there, at least in that period. The functioning of the news network thus depended also on the degree of connection with each 'terminal node'.

The degree of sensitivity to natural calamities depended also on the relationship between centre and periphery. On 4 December 169o, a strong earthquake hit Carinthia, the Austrian Duchy at the border of the Venetian Republic. According to most of the sources, the earthquake caused extensive damage and death at Villach and in the neighbouring villages of Töbrig and Wernbeg, as well as heavy damage at Klagenfurt and other nearby villages. The quake was also strongly felt in Venice, where some chimneys fell, and was perceived throughout Germany, Slovenia and Bohemia. However, news about the most important effects, that is those from the epicentral zone, did not reach readers of the newspapers printed in London and Paris. Instead, information from Villach arrived in Venice and it was from there that it was sent to other gazette editors in Mantua and Bologna.

It is useful at this point to summarise how the network functioned through the four newspapers mentioned above. News about the event was disseminated through the most important capitals of the region: Vienna and Venice. In all four gazettes, the news from Vienna about the earthquake was published with the dateline of 10 December $1690 .{ }^{85}$ The texts published in the English and French newspapers have similar features, and so probably derived from the same source, while those printed in the Italian gazettes are different translations of the same text. In any case, none of them had news from Vienna with information about the aftermath of the earthquake in the epicentral zone. Instead, according to the succeeding issues, damage in Vienna and elsewhere was produced by a violent wind that harmed many buildings. ${ }^{86}$

The news from Venice also apparently drew on two correspondents: the news that had reached the Paris and London gazettes mentioned with similar texts that the earthquake had been felt there. ${ }^{87}$ On the contrary, the Venetian correspondents of 9 December in the gazettes of Bologna and Mantua did not mention the earthquake, even though it had been strongly felt in the city. Yet,

85 See the correspondence from Vienna in: The London Gazette (18-22 December 169o); Gazette, no. 55 (30 December 169o); Mantova, no. 51 (22 December 169o) and Bologna (30 December 169o). Except the gazette printed in Mantua, these newspapers are available at <www.thegazette.co.uk/all-notices $>$, and <badigit.comune.bologna.it/Gazzette/ gazzettedefault.asp $>$ [4/5/15]. For the Parisian Gazette, see note 80.

86 Gazette, no. 1 (6 January 1691).

87 Like in the case of the correspondence from Vienna, the English newspaper gave more details than the French one: see 'Venise, le 8 Decembre 169o' in the Gazette, no. 55 (30 December, 169o), and 'Venice, December 8', in The London Gazette, 22-24 December 1690. 
in the following issues of these Italian gazettes, the Venetian correspondent mentions letters that had come from Villach: "Venice, 16 December [...] By letters from Villach, Austrian State, it is reported that at the same time as the first earthquake was felt here, it was felt also in that city, with heavy damage, and it says that half of that city was destroyed, with 30 dead and many wounded". 88

Despite its limitations, at the end of the seventeenth century the news network supplied information at least about the most important events within the bounds of Christendom, and about many outside them. Although the prominence accorded to them varied, depending on the interests and stance of each editor, news of natural calamities were widely disseminated at the end of the pre-Enlightenment period. For instance, the news of the great storm that struck southern England and Wales between 7 and 8 December (26-27 November old style) 1703 was received in the Low Countries as well as in northern Italy, but occupied much more space in the fortnightly Amsterdam gazette than in Mantua's weekly newspaper. ${ }^{89}$ Nevertheless, being nearer to the event did not warrant providing good quality information nor news at all. When in 1726 a rather small earthquake caused some damage in Dozza, in the Papal Legation of Bologna, the local as well other Italian gazettes neglected to mention the event. It was, however, reported in a Viennese gazette. The source of the Austrian official newspaper seems to have been the translation of the Bologna's manuscript newssheets, which reported weekly on local events. ${ }^{90}$ In this case editorial conditions, for instance the space available for writing news, could be another key to understand the functioning of news circulation. The Gazette printed in Bologna issued weekly in a four-page edition, amounting to 208 pages of news each year. The Wienerisches Diarium appeared twice a week and was at least seven pages long, giving 728 pages of news each year. Renaudot's Gazette was a twelve-page weekly, totalling 624 pages annually.

The circulation of news was influenced to some degree by political conditions. For example, when in 1726 , while Sicily was under Imperial rule, Palermo was rocked by an earthquake, Mantua's gazette received news from Palermo through correspondents from Naples, Genoa and Livorno: the other important Tyrrhenian ports, in other words. Bologna's gazette received news of the event

\footnotetext{
88 Bologna (19 December 1690), and Mantova (22 December 169o).

89 Compare the gazette of Amsterdam (18 and 21 December 1703: datelines London 11 and 14 December) with that of Mantova (9 and 16 January 1703: datelines London 8 and 14 December).

9o See Wienerishes Diarium, 20 February 1726. About Bologna's Avvisi, see Carlos H. Caracciolo, 'Los avisos secretos de Bolonia: un caso de periodismo de "provincia", in Géneros editoriales, 45-69. See also Romano Camassi, et al., 'Materiali per un catalogo dei terremoti italiani', Quaderni di Geofisica, 57 (2008), no. 9o, p. 148.
} 
from Rome, while the Gazette of Vienna (and that of Amsterdam) got their news directly from Palermo; it also borrowed from the other Italian gazettes mentioned above and, moreover, published a very detailed news pamphlet and a broadsheet in addition to the periodical gazette. ${ }^{91}$

The patterns of reporting of natural disasters can also be shown to be contingent on the geographic characteristics of the events themselves. Floods, for instance, can cause damage across large areas which in some cases may activate different nodes of the information network, as in the instance of the thaw in the cities situated along the Lower Rhine. ${ }^{92}$ In the pages of the gazette printed in Bologna, there would be information practically every year about floods in northern Europe with datelines from Cologne, Frankfurt and London, but also from Paris and Venice. The natural phenomenon might be only a passing detail within a news report carrying more important information, as in the case of a correspondence from Cologne, which reported that the military chief of Bonn continued to reinforce the city defences though 'persistent rain [had] inundated the nearby lands. ${ }^{93}$

At the same time it was possible to read news about the Mediterranean earthquakes from the French and Austrian official Gazettes. Moreover, news about natural disasters arrived from the frontiers of the Western world, and sometimes even beyond. When Algiers was rocked by an earthquake in 1716, the news published on 29 February by the French gazette arrived directly from the African port, with the information dated 5 February. It recounted the damage to the city as well as to the French Consul's house. Meanwhile, readers of Bologna's gazette first heard about it on the 7 April (datelined Genoa, 29 March), with information from Cagliari (Sardinia), along with an English ship, which had stopped at Algiers and Port Mahon. The next correspondences (Genoa, 5 and 12 April) said nothing about the earthquake. The correspondence from Genoa dated 19 April reported four ships that had arrived with news from western Mediterranean ports; one of them, an English ship arrived from Majorca loaded with oil, confirmed the news about the earthquake in Algiers. One month later, further correspondence from Genoa (19 May) mentioned a 'relation' in which it said the toll of victims caused by the earthquake was 22,000 people, amongst them 800 Christians, "with the destruction of almost the entire city" of Algiers, "except a few houses near the coast". Other

91 See Wienerisches Diarium, from 2 October to 13 November 1726. Available on <anno.onb .ac.at/cgi-content/anno?datum $=1726 \&$ zoom $=33>[4 / 5 / 15]$. 28 February, 13 and 26 March, 1709 . 
interesting cases were the earthquake that rocked Boston and the east coast of the English colonies in north America, and the eruption of the volcano Krafla, in Iceland, of which news reached the Paris Gazette via Copenhagen at the end of 1729 and the Viennese gazette via Hamburg. ${ }^{94}$ In fact news of the eruption arrived only in its final phase, when the lava had already destroyed some farms and menaced a village. News also came from very distant places. The Wienerisches Diarium, received news on 9 September 1729 from St Petersburg (6 August) of an earthquake of October 1728 in Peking. Some days earlier, news about this earthquake reached Paris by a different route: via Madrid (9 August), which reported news received from Lisbon. This news accompanied information about an important battle in the Great Tibet, which, according to the correspondents, signalled Chinese dominion over that land. ${ }^{95}$

\section{Conclusions}

The events and the news described above should provide some keys for a better understanding of the relationship between natural disasters and the news network. For instance, it is useful to distinguish between two aspects of the news network: the capacity to collect information about natural calamities, and the ability to disseminate them as news. In the middle, the network had two levels: local or national (characterised by linguistic rather than political boundaries), and international or translinguistic. Levels and links between them developed during this period, along with the degree of sensitivity of the network to natural catastrophes.

At the beginning of the sixteenth century, printed news about natural calamities was rare. Nevertheless, manuscript newssheets and printed pamphlets created some space for accounts of them in the news market. From the beginning, news about natural catastrophes drew the attention of the foreign public, as in the cases of the earthquakes in northern Africa and Spain (1522) and in Tuscany (1542). Most news of floods and earthquakes during this period came from printers operating in the linguistic region in which the disaster occurred, however. News about natural calamities, when it crossed linguistic borders, usually travelled from south to north, mostly from Italy and the Levant to France and Germany. Moreover, relatively few such events during the sixteenth century were covered by the news network. Coverage depended on where events occurred, and on their position in the news network, rather than

94 Gazette (24 and 31 December 1729); Wienerisches Diarium (4 January 1730).

95 Wienerisches Diarium, no. 72 (7 September 1729), Gazette, no. 35 (27 August, 1729). 
on the significance of the event in respect of the damage it caused. These assumptions continue to hold during the seventeenth century, especially for news pamphlets. The situation changed radically with the diffusion of newspapers, however. If almost all news pamphlets about natural calamities catalogued by Sandro and Tullio Bulgarelli for the seventeenth century occurred in the Italian peninsula, the news issued in the newspapers dramatically expanded the geographical range over which disasters were reported. For instance, news about the earthquakes that struck southern Spain (1680), Germany (1681), and Turkey (1688) were published in the gazette of Bologna, but passed unnoticed by any Italian pamphlets. Newspapers at once incorporated news pamphlets into their own system, printing them as supplements to the periodical issues, and increased the level of sensitivity to natural phenomena, providing news about minor events that would have been very unlikely to find space in news pamphlets. It is likely that this augmented sensitivity has its origin in the more intensive use of the information networks established by the newspaper editors.

Whether or not translinguistic links were reinforced by newspapers, local networks seem to be underdeveloped, as in the case of the Eastern Alps earthquake in 1690, news of which reached Venice via a surprisingly roundabout route. It is of course possible that the Venetian correspondent had limited interest in natural phenomena, because he neglected to report how the earthquake was felt in the city, although he was able to collect information when the event appeared serious. Informal sources became important means of newsgathering where there was a discernible interest in these types of events and where the network was not yet comprehensive, as in the case of the 1716 Algerian earthquake.

By the beginning of the eighteenth century, newspapers had become the principal axis around which the news network pivoted. Beyond political, geographical and editorial conditions, an extended information network enabled the collection and dissemination of news over a large part of the continent during the pre-Enlightenment period. When on 1 November 1755 a very strong earthquake destroyed Lisbon and many other towns and generally affected areas in Portugal, Spain and Morocco, an extended and well consolidated news network existed to report it all over Europe and beyond. 